\title{
Content
}

\section{Thomas Hansen}

Cyrtometopinid trilobites from the upper Volkhov and lower Lynna

Formations (lower Darriwilian) of NW Russia.

Lars O. Boldreel, Antoon Knipers, Emil B. Madsen, Christian Has,

Sebastian Lindhorst, Rasmus Rasmussen, Maya G. Nielsen, Jesper Bartholdy

\& Jørn B.T. Pedersen

Postglacial sedimentary regime around northern Sylt,

south-eastern North Sea, based on shallow seismic profiles....................... 15

Thomas Weidner \& Arne Thorshøj Nielsen

Yuepingia? sp., a ceratopygid trilobite from the upper Cambrian (Furongian) of Scandinavia.

Paul M. Holm, L.E. Pedersen \& B. Højsteen

Geochemistry and petrology of mafic Proterozoic and Permian dykes on Bornholm, Denmark: Four episodes of magmatism on the margin of the Baltic Shield ............................................................................................. 35

Aaron W. Hunter \& Jan Rees

A new echinoderm faunule from the Lower Jurassic (Pliensbachian) of southern Sweden.

Sven Karup-Møller, John Rose-Hansen \& Henning Sørensen Eudialyte decomposition minerals with new hitherto undescribed phases from the llímaussaq complex, South Greenland

Finn Surlyk, Lars Stemmerik, Morten Ahlborn, Rikke Harlou, Bodil W. Laurids.... 75

Susanne L. Rasmussen, Niels Schovsbo, Emma Sheldon \& Nicolas Thibault The cyclic Rørdal Member - a new lithostratigraphic unit of chronostratigraphic and palaeoclimatic importance in the upper Maastrichtian of Denmark.

Finn Surlyk, Lars Ole Boldreel, Holger Lykke-Andersen \& Lars Stemmerik The Skælskør structure in eastern Denmark - wrench-related anticline or primary Late Cretaceous seafloor topography?.

\section{Bulletin of the} Geological Society of Denmark

9

VOLUME 58 | DECEMBER 2010 | COPENHAGEN

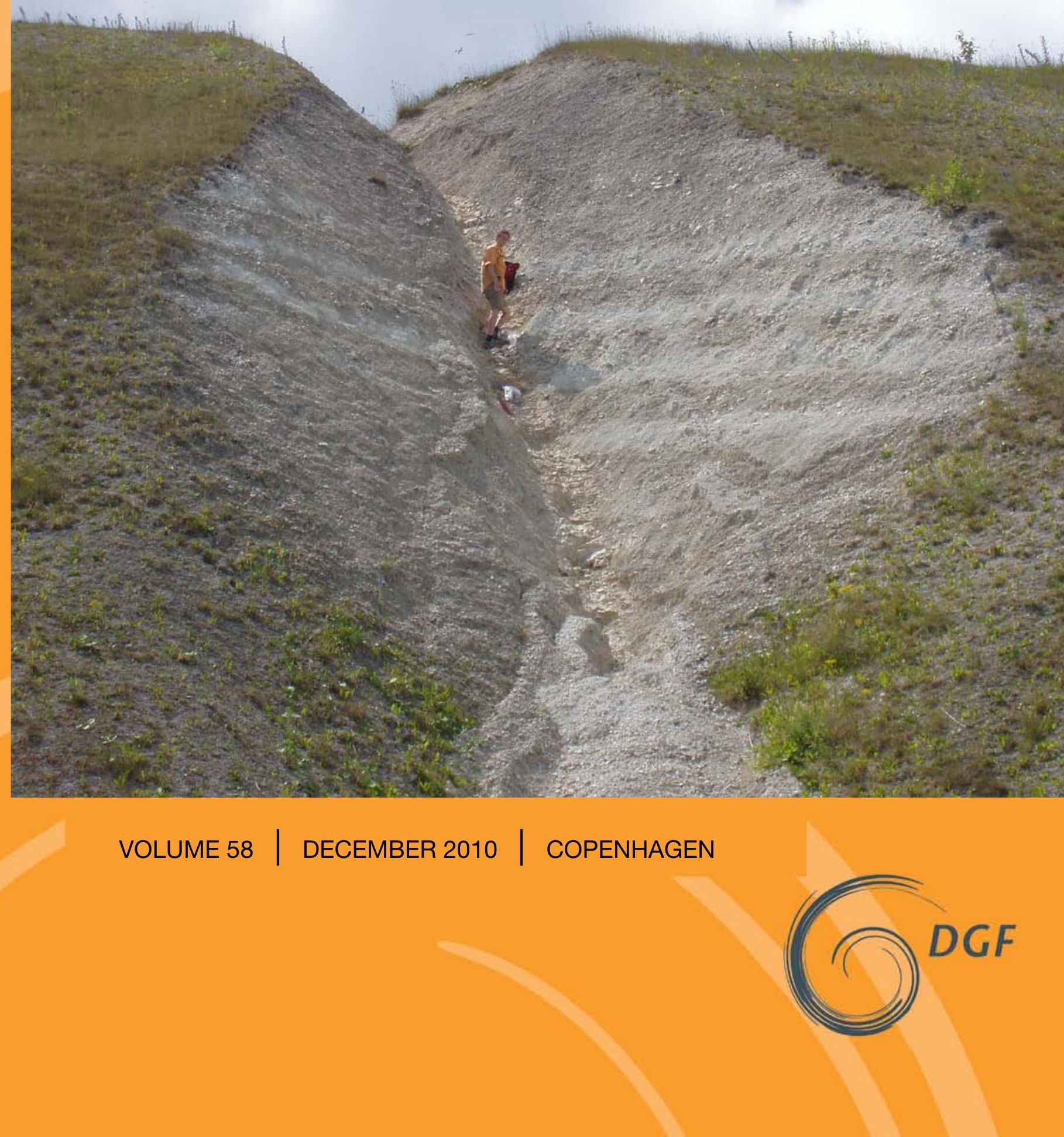


Chief editor

Karsten Secher, Geological Survey of Denmark and Greenland (GEUS), Øster Voldgade 10, Tel: +45 38142236; Fax: 4538142220 E-mail: kse@geus.dk

Scientific editors

Lars Clemmensen, Dept. of Geography and Geology, Universtiy of Copenhagen, Øster Voldgade 10,

Tel: 45 3532 2476; E-mail: larsc@geol.ku.dk

Ole Graversen, Dept. of Geography and Geology, University of Copenhagen, Øster Voldgade 10, DK-1350 Copenhagen K, Denmark.

Tel: +45 3532 2447; E-mail: oleg@geol.ku.dk

Claus Heinberg, Institute of Environment, Technology and Society, University of Roskilde, P.O. Box 260, DK 4000 Roskilde, Denmark. Tel: +45 46742299 ;

E-mail:

Michael Houmark-Nielsen, Dept. of Geography and Geology, University of Copenhagen, Øster VoldTel: +45 3532 2486; E-mail: michalh@geolku

Lars Nielsen, Dept. of Geography and Geology, University of Copenhagen, Øster Voldgade 10 DK-1350 Copenhagen K, Denmark

Tel: +45 3532 2454; E-mail: In@geol.ku.dk

Erik Thomsen, Department of Earth Sciences, University of Aarhus C.F. Møllers Allé, Denmark. Tel: +4533634000

E-mail: erik.thomsen@geo.au.dk

Henrik Tirsgaard, Mærsk Olie og Gas AS, Esplanaden 50, DK-1263 Copenhagen K Denmark. Tel: +4533634000

J. Richard Wilson, Department of Earth Sciences, DK-8000 Aarhus C, Denmark. Tel: +45 8942 2526; E-mail: jrw@geo.au.dk http:/ /2dgf.dk/publikationer/bulletin/ vejledning.html

Manuscripts will be reviewed by two referees and will appear approximately in the order in which they are accepted for pubbe accepted for publication rests with the editor, acting, when necessary, on the advice of the editorial board. The final versio of the manuscript should be submitted as a paper copy and as be submitted as computer files.

The type section of the Rørdal Member in the south-wester high. Photo: Finn Surlyk.
Language - Manuscripts should be in English. Authors who are not proficient in English should ask an English-speaking col-

Title - Titles should be short and concise, with emphasis on words useful for indexing and information retrieval. An submitted.

Abstract - An abstract in English must accompany all papers. It should be short (no longer than 250 words), factual, and wits with a list of key words.

Danish summary - Authors are encouraged to deliver a shor summary in Danish to follow the main text.

Main text - Use double spacing throughout, and leave a wide left margin $(3.5 \mathrm{~cm})$. Italics should be used only in generic et al., ibid., op. cit). Use at most three grades of headings, but do not underline or capitalize. Indicate figure and table placement in pencil in the left margin.

References to figures, tables and papers - References to figures and 3 or as (Smith 1969, fig. 3) when the reference is to a figure in a cited paper- - References to papers are given in the form Smith (1969) or (Smith 1969). Combined citations by different authors are separated by a semicolon; two or more papers by same author(s) are separated by commas. Citations are places chronologically and hen diphabetically. Use'e

\section{References}

1: Alphabetically by the first author's surname Papers by one author: two or more papers are arranged Papers by two authors: alphabetically after second author's name. Two

logically.

Pe sy three or more authors: chronologically. Papers from are arranged alphabetically after second, third,

thors themselves are responsible for the accuracy and completeness of their references. If incorrect references are detected the manuscript will be returned to the author for conty the references cited in the paper (including all, and tables etc).

Spelling - Geological units named after localities in Greenland formal lithostratigraphical units and intrusions named after localitites in Greenland remain unchanged even if the eponymous locality names have sincebeen changed with modern Greenlandic orthography

\section{Illustrations}

Illustrations - should be prepared for black and white printing on one page unless author pays for the extra printing costs related to colour printing or foldouts. Horizontal illustration are much to be preferred. Size of smallest letters in ill

Submit copies of figures, tables, plates, etc. together with the manuscript. All figures (including photographs) should be submitted in electronic form ready for direct reproduction i.e. having the dimensions of the final figure with a standard resolution of $300 \mathrm{dpi}$ for photographs. Preferred formats a pdf, eps, tiff and jpg.

Reference list

Danish letters $æ, \varnothing$ and å (aa) are treated as ae, o and a (aa), respectively. - Use following style

Smith, A.A. 1989: Geology of the Bulbjerg Formation. Bulletin of the Geological Society of Denmark 38, 119-144. [Note that name of journal is given in full].

Smith, A.A.., Jensen, B.B. \& MacStuff, C.C. 1987: Sandstones of Denmark, 2nd edition, 533 pp. New York: Springer Verlag

Smith, A.A.., Jensen, B.B. \& MacStuff, C.C. 1992: Characterization of Archean volcanic rocks. In: Hansen, D.D. et al. (eds) Geology of Greenland. Geological Survey of Denmark and therefore et al. form is used].
Maximum height is $232 \mathrm{~mm}$. ered on separate pages. of DKK 3200 excl. VAT pr. article (max 16 pages)

Proofs and Offprints

Proofs - Authors receive one set of page proofs. Prompt return to the editor is requested. The cost of any alterations against the final manuscript will be charged to the author.

ffprint - One copy of the printed volume and a free pdf-file is supplied to the authors. Paper copies may be ordered at of copies and the address to which the offprints and invoice should be sent. 